\title{
Oxygen saturations in premature infants at resuscitation. Where is the evidence?
}

\author{
Vasantha HS Kumar* \\ Department of Pediatrics, University at Buffalo, The State University of New York, Buffalo, NY, USA
}

\section{Introduction}

Premature infants $<32$ weeks' gestation often require resuscitation during fetal to neonatal transition, which includes administration of supplemental oxygen. Hyperoxia is one of the important generators of reactive oxygen species (ROS) and excess ROS is kept in check by antioxidant defense mechanisms. Premature infants have reduced antioxidant defense mechanisms at birth and hence are at risk for toxic effects of oxygen [1]. Supplemental oxygen in premature infants contributes to development of bronchopulmonary dysplasia (BPD) [2], retinopathy of prematurity [3] and brain injury [4]. The awareness of oxygen toxicity in premature infants has led to strategies such as limiting oxygen exposure at birth, use of antioxidants and administering room air at neonatal resuscitation to reduce free radical formation and to optimize long term outcomes.

Numerous studies have defined the percentiles of oxygen saturation as a function of time from birth in uncompromised babies born at term $[5,6]$. Neonatal resuscitation guidelines in 2010 for the first time recommended the targeted preductal saturations $\left(\mathrm{SpO}_{2}\right)$ at resuscitation in the first 10 minutes after birth [7]. The $\mathrm{SpO}_{2}$ guidelines were applicable for both term and premature infants, to be achieved by initiating resuscitation with air or blended oxygen and titrating the oxygen concentration to achieve an $\mathrm{SpO}_{2}$ in the target range using pulse oximetry [7]. Oxygen concentration is increased to $100 \% \mathrm{O}_{2}$ in a bradycardic (heart rate $<60 / \mathrm{min}$ ) infant after 90 seconds of resuscitation with a lower concentration of oxygen, until the heart rate recovers to normal. The $2015 \mathrm{NRP}$ guidelines maintained the same saturation targets, recommended against using high $\mathrm{O}_{2}$ concentrations of $65 \%$ to $100 \% \mathrm{O}_{2}$ and to initiate resuscitation with $21 \%$ to $30 \% \mathrm{O}_{2}[8]$.

\section{Evidence with $30 \% \mathrm{O}_{2}$ at resuscitation}

The three studies that administered $30 \% \mathrm{O}_{2}$ as one of the oxygen resuscitation groups are summarized in Table 1 . Escrig et al was the first to demonstrate that $30 \% \mathrm{O}_{2}$ can safely be used to resuscitate premature neonates, which can then be adjusted to infant's needs reducing the oxygen load on the infant [9]. Vento et al. later demonstrated that $30 \% \mathrm{O}_{2}$ for resuscitation, leads to less oxidative stress, inflammation, decreasing the incidence of $\mathrm{BPD}^{10}$. However, a recent study with $30 \% \mathrm{O}_{2}$ did not find differences in oxidative stress markers or BPD among the two resuscitation groups [11] (Table 1). This may be related to differences in target saturations among the groups in the first 10 minutes; changes in oxygen load from differences in the high oxygen resuscitated group $\left(90 \% \mathrm{O}_{2}[10]\right.$ versus $\left.65 \% \mathrm{O}_{2}[11]\right)$ at resuscitation and finally from varying definitions of BPD at 36 weeks (physiologic or clinical) among the groups [10,11]. Despite using diverse target saturations in the first 10 minutes, all the three studies demonstrate the feasibility of administering $30 \% \mathrm{O}_{2}$ at resuscitation in premature infants. The oxygen concentration was titrated upwards to meet $\mathrm{SpO}_{2}$ targets in all studies: to $40 \%$ [11], $45 \%{ }^{9}$ or $55 \% \mathrm{O}_{2}$ [10] by 5 minutes of birth. The studies indicate that $30 \% \mathrm{O}_{2}$ can be used as a starting point to resuscitate a premature infant. The clinical outcomes need to be confirmed, as all these studies used varying target saturations in the first 10 minutes.

\section{Evidence with $21 \% \mathrm{O}_{2}$ at resuscitation}

Five studies that administered $21 \% \mathrm{O}_{2}$ as one of the oxygen resuscitation groups are summarized in Table 2. In the three studies wherein the infants were resuscitated in $21 \% \mathrm{O}_{2}$ [12-14], room air failed to maintain the targeted $\mathrm{SpO}_{2}$ and almost all infants required supplemental oxygen. However, resuscitation in $100 \% \mathrm{O}_{2}$ resulted in hyperoxic infants with $\mathrm{SpO}_{2}>95 \%$ [13]. Oxygen titration strategy after initial resuscitation with $100 \% \mathrm{O}_{2}$ resulted in higher number of infants achieving targeted saturations [13]. The studies imply, that if premature infants were initially resuscitated with $21 \% \mathrm{O}_{2}$, then careful attention should be placed to heart rate and $\mathrm{SpO}_{2}$, so that the oxygen can be titrated upwards to achieve saturations as per neonatal resuscitation guidelines.

Studies conducted with $21 \% \mathrm{O}_{2}$ as one of the resuscitation group, had the same drawbacks as the studies conducted with $30 \% \mathrm{O}_{2}$ resuscitation group. No two resuscitation studies conducted so far (including $21 \% \mathrm{O}_{2}$ and $30 \% \mathrm{O}_{2}$ resuscitation groups; (Table 1,2) had similar saturation targets in the first 10 minutes after birth. Neonatal resuscitation program (NRP) guidelines recommends that the goal in babies resuscitated at birth, whether born at term or preterm, should be an oxygen saturation value in the interquartile range of preductal saturations measured in healthy term babies following vaginal birth at sea level [7]. The guidelines recommend preductal $\mathrm{SpO}_{2}$ of $60 \%-65 \%$ at $1 \mathrm{~min} ; 65 \%-70 \%$ at $2^{\text {nd }} \mathrm{min} ; 70 \%-75 \%$ at $3^{\text {rd }} \mathrm{min} ; 75 \%-80 \%$ at $4^{\text {th }}$ min and $80 \%-85 \%$ at the end of 5 minutes. The $\mathrm{SpO}_{2}$ values between 5 and 10 minutes of life should be $85 \%$ - 95\% [7]. These targets should be achieved by initiating resuscitation with a low oxygen concentration $\left(21 \% \mathrm{O}_{2}-30 \% \mathrm{O}_{2}\right)$ and to titrate the $\mathrm{O}_{2}$ to achieve an $\mathrm{SpO}_{2}$ in the target range using pulse oximetry [8]. The guidelines also recommend against

Correspondence to: Vasantha HS Kumar, Division of Neonatology, Department of Pediatrics, The Women \& Children's Hospital of Buffalo, University at Buffalo, 219 Bryant Street, Buffalo, NY 14222-2006, USA, Tel: +1 716878 7673; Fax: +1 716878 7945; E-mail: vkumar3@buffalo.edu

Key words: resuscitation, oxygen, $\mathrm{Sp} \mathrm{O}_{2}$, premature infants

Received: June 09, 2016; Accepted: July 06, 2016; Published: July 11, 2016 
Table 1. Studies That Administered $30 \% \mathrm{O}_{2}$ as the Initial Gas at Resuscitation in Premature Infants.

\begin{tabular}{|c|c|c|}
\hline Study & Methods / Groups & Results / Conclusions \\
\hline $\begin{array}{l}\text { Escrig et al. } 2008 \\
(\leq 28 \text { wks GA })\end{array}$ & $\begin{array}{l}30 \% \mathrm{O}_{2}(\mathrm{n}=19 ; \text { lox grp }) v s .90 \% \mathrm{O}_{2}(\mathrm{n}=29 ; \text { hox grp }) \\
\text { Target } \mathrm{spo}_{2}-\mathrm{FiO}_{2} \text { adjustment based on } \mathrm{HR} ; \mathrm{spo}_{2} \text { between } 85-90\end{array}$ & $\begin{array}{l}\mathrm{FiO}_{2} \uparrow \text { stepwise to } \sim 45 \% \text { in LOX; } \downarrow \text { to } 45 \% \mathrm{O}_{2} \text { in } \mathrm{HOX} \text { for a spo } \mathrm{spo}_{2} \text { oround } \\
85 \% \text { at } 5-7 \text { minutes in both groups. No difference in morbidity including BPD } \\
\text { and ROP. No deaths }<28 \text { days in both groups. }\end{array}$ \\
\hline $\begin{array}{l}\text { Vento } \text { et al. } 2009 \\
(24-28 \text { wks GA) }\end{array}$ & $\begin{array}{l}30 \% \mathrm{O}_{2}(\mathrm{n}=37 ; \text { lox grp }) v s .90 \% \mathrm{O}_{2}(\mathrm{n}=41 ; \text { hox grp }) \\
\text { Target } \mathrm{spo}_{2}-\text { preductal } \mathrm{spo}_{2} \text { of } 75 \% \text { at } 5 \mathrm{~min} \text { and } 85 \% \text { at } 10 \mathrm{~min}\end{array}$ & $\begin{array}{l}\mathrm{FiO}_{2} \uparrow \text { stepwise to } \sim 55 \% \text { at } 5 \mathrm{~min} \text {; lower incidence of BPD \& less markers of } \\
\text { oxidative stress (urine / GSSG/GSH) in the LOX group. }\end{array}$ \\
\hline $\begin{array}{l}\text { Rook et al. } 2014 \\
(<32 \text { wks GA })\end{array}$ & $\begin{array}{l}30 \% \mathrm{O}_{2}\left(\mathrm{n}=99 ; \text { lox grp) } v s .65 \% \mathrm{O}_{2}(\mathrm{n}=94 ; \text { hox grp })\right. \\
\text { Target } \mathrm{spo}_{2}-\mathrm{FiO}_{2} \downarrow \text { for } \mathrm{spo}_{2}>94 \% ; \mathrm{FiO}_{2} \uparrow \text { for } \mathrm{HR}<100 / \mathrm{min} \\
\text { before } 10 \mathrm{~min}\end{array}$ & $\begin{array}{l}\mathrm{FiO}_{2} \uparrow \text { stepwise to } \sim 40 \% \text { by } 7 \mathrm{~min} \text { in } \mathrm{LOX} ; \mathrm{FiO}_{2} \downarrow \text { to } \sim 40 \% \text { by } 11 \mathrm{~min} \text { in } \\
\mathrm{HOX} \text { group; No difference in oxidative stress markers or BPD between } \\
\text { groups }\end{array}$ \\
\hline
\end{tabular}

Table 2. Studies That Administered $21 \% \mathrm{O}_{2}$ as the Initial Gas at Resuscitation in Premature Infants.

\begin{tabular}{|c|c|c|}
\hline Study & Methods / Groups & Results / Conclusions \\
\hline $\begin{array}{l}\text { Wang } \text { et al. } 2008 \\
(23-32 \text { wks GA) }\end{array}$ & $\begin{array}{l}21 \% \mathrm{O}_{2}(\mathrm{n}=18) v s .100 \% \mathrm{O}_{2}(\mathrm{n}=23) \\
\text { Target } \mathrm{SpO}_{2}-100 \% \mathrm{O}_{2} \text { grp: } \mathrm{FiO}_{2} \downarrow \text { for } \mathrm{spo}_{2}>95 \% \text { at } 5 \mathrm{~min} .21 \% \text { grp } \\
-\uparrow \mathrm{FiO}_{2} \text { for spo } 2<70 \% \text { at } 3 \mathrm{~min} \text { or for } \mathrm{spo}_{2}<85 \% \text { at } 5 \mathrm{~min}(\uparrow \text { to } 50 \% \\
\left.\mathrm{X} 30 \text { secs; no response } \uparrow \text { to } 75 \% \mathrm{X} 30 \text { secs; no response }-\uparrow 100 \% \mathrm{O}_{2}\right)\end{array}$ & $\begin{array}{l}\text { All infants resuscitated in the RA received } \mathrm{O}_{2} \leq 3 \mathrm{~min} \text {; Resuscitation with RA } \\
\text { failed to achieve targeted } \mathrm{spo}_{2} \text { by } 3 \text { minutes; recommend not to use RA for } \\
\text { resuscitation of premature neonates. }\end{array}$ \\
\hline $\begin{array}{l}\text { Dawson } \text { et al. } 2009 \\
(<30 \text { weeks GA) }\end{array}$ & $\begin{array}{l}21 \% \mathrm{O}_{2}(\mathrm{n}=105) \text { vs. } 100 \% \mathrm{O}_{2}(\mathrm{n}=20) \\
\text { Target } \mathrm{SpO}_{2}-80 \text { to } 90 \% ; \mathrm{FiO}_{2} \downarrow \text { by } 10 \% \text { if } \mathrm{spo}_{2}>90 ; \mathrm{FiO}_{2} \uparrow \text { for } \mathrm{spo}_{2} \\
<70 \% \text { at } 5 \mathrm{~min} \text { or } \mathrm{spo}_{2}<90 \% \text { at } 5 \mathrm{~min}+\mathrm{HR}<100\end{array}$ & $\begin{array}{l}97 / 105(92 \%) \text { in the } 21 \% \mathrm{O}_{2} \text { group were subsequently treated with supplemental } \\
\mathrm{O}_{2} \text { at } 5.05(4-5.5) \mathrm{min} .\end{array}$ \\
\hline $\begin{array}{l}\text { Rabi et al. } 2011 \\
(<32 \text { wks GA })\end{array}$ & $\begin{array}{l}21 \% \mathrm{O}_{2}\left(\mathrm{Low} \mathrm{O}_{2} \text { strategy; titrate up; } \mathrm{n}=34\right) ; 100 \% \mathrm{O}_{2} \text { and then wean } \\
\left(\text { mod. } \mathrm{O}_{2} \text { strategy) }(\mathrm{n}=34) ; 100 \% \mathrm{O}_{2}\left(\text { high } \mathrm{O}_{2} \text { strategy; } \mathrm{n}=37\right) ;\right. \\
\text { Target } \mathrm{spo}_{2}-\mathrm{FiO}_{2} \text { adjusted } 20 \% \mathrm{O}_{2} \text { q } 15 \text { secs to achieve } \mathrm{spo}_{2} \text { of } \\
85-92 \%\end{array}$ & $\begin{array}{l}\text { Titrating down from } 100 \% \mathrm{O}_{2} \text { was more effective at maintaining spo } \mathrm{s}_{2} \text { in the } \\
\text { range of } 85-92 \text { and these infants spent nearly twice as long in the target range } \\
\text { as infants resuscitated in } 21 \% \mathrm{O}_{2} \text {. }\end{array}$ \\
\hline $\begin{array}{l}\text { Kapadia } \text { et al. } \mathbf{2 0 1 3} \\
(24-34 \text { wks GA })\end{array}$ & $\begin{array}{l}21 \% \mathrm{O}_{2}(\mathrm{n}=44 ; \text { lox grp }) v s .100 \% \mathrm{O}_{2}(\mathrm{n}=44 \text {; hox grp }) \\
\text { Target } \mathrm{SpO}_{2}-21 \% \mathrm{O}_{2} \text { grp: NRP guidelines; } 100 \% \mathrm{O}_{2} \text { grp: } \mathrm{FiO}_{2} \\
\text { adjusted by } 10 \% \text { to target spo of } 85-94\end{array}$ & $\begin{array}{l}\text { Lox decreased oxygen load by half; had less oxidative stress at one hour of age } \\
\text { and reduced incidence of BPD }\end{array}$ \\
\hline $\begin{array}{l}\text { Kumar et al. } 2014 \\
(24-32 \text { wks GA) }\end{array}$ & $\begin{array}{l}21 \% \mathrm{O}_{2}(\mathrm{n}=6) v s .40 \% \mathrm{O}_{2}(\mathrm{n}=7) v s .100 \% \mathrm{O}_{2}(\mathrm{n}=5) \\
\frac{\text { Target spo }}{2}-\text { First } 10 \text { min of birth no change in } \mathrm{FiO}_{2} \text { and } \mathrm{spo}_{2} \text { were } \\
\text { blinded; } 100-30 \text { min: } \mathrm{spo}_{2}<85 \% \uparrow \mathrm{FiO}_{2} \text { and } \mathrm{spo}_{2}>95 \% \downarrow \mathrm{FiO}_{2} 10 \% \\
\text { q 60secs }\end{array}$ & $\begin{array}{l}\text { Defined the natural evolution of } \mathrm{spo}_{2} \text { in three different } \mathrm{O}_{2} \text { concentrations in the } \\
\text { first } 10 \text { minutes; } 21 \% \mathrm{O}_{2} \text { had } \mathrm{spo}_{2} \text { below the NRP-LL in the first } 5 \text { min; } 40 \% \mathrm{O}_{2} \\
\text { mostly within the NRP limits; } 100 \% \mathrm{O}_{2} \text { leads to higher total } \mathrm{O}_{2} \text { exposure and } \\
\text { systemic oxidant stress }\end{array}$ \\
\hline
\end{tabular}

initiating resuscitation of premature infants with high supplementary oxygen concentration $\left(65 \% \mathrm{O}_{2}-100 \% \mathrm{O}_{2}\right)$ [8]. Limiting oxygen exposure at resuscitation by starting low $\left(21 \% \mathrm{O}_{2}-30 \% \mathrm{O}_{2}\right)$ and titrating the oxygen concentration upwards to target the above saturation limits in the first ten minutes after birth, not only decreases the oxygen load but may also decrease the risk for BPD [10].

The 2010 guidelines states that the saturation data are extrapolations from term infants [7]. The lack of induction of anti-oxidant enzyme systems soon after birth [15] along with generation of ROS by hyperoxia, makes it highly likely that the suggested $\mathrm{SpO}_{2}$ targets in the first 10 minutes after birth are 'relatively hyperoxic' for premature infants. The physiology of oxyhemoglobin curves is different in term and premature infants [16-18]. Maintaining similar saturations in both term and preterm infants may lead to higher oxygen delivery, higher oxidant load and downregulation of hypoxia inducible factor (HIF-1) and vascular endothelial growth factor (VEGF) expression in premature infants. HIF-1 expression is tightly linked to $\mathrm{O}_{2}$ concentration in vivo and hyperoxia or even normoxia in the developing lung rapidly induce HIF degradation and hence VEGF expression [19]. Future studies should address $\mathrm{SpO}_{2}$ ranges in premature infants, particularly in the first 10 minutes after birth. The question is, what is the natural evolution of $\mathrm{SpO}_{2}$ in premature infants resuscitated in room air in the first ten minutes after birth and how do they compare to the limits set by NRP?

This was addressed in a small pilot study in infants $<32$ weeks GA, randomized to $21 \%, 40 \%$ or $100 \% \mathrm{O}_{2}$ and resuscitated as per
$2005 \mathrm{NRP}$ guidelines [20]. Oxygen groups and $\mathrm{SpO}_{2}$ were unmasked at 10 minutes of age and $\mathrm{FiO}_{2}$ adjusted to maintain $\mathrm{SpO}_{2}$ of $85 \%-95 \%$ for the next 20 minutes. The study was stopped at $30 \%$ enrollment following publication of the $2010 \mathrm{NRP}$ guidelines. The mean $\mathrm{SpO}_{2}$ values were $50 \%, 53 \%$ and $69 \%$ at $1 \mathrm{~min} ; 77 \%, 83 \%$ and $95 \%$ at $5 \mathrm{~min}$ and $92 \%, 92 \%$ and $98 \%$ at $10 \mathrm{~min}$ in $21 \% \mathrm{O}_{2}, 40 \% \mathrm{O}_{2} \& 100 \% \mathrm{O}_{2}$ groups respectively (Figure 1) [20]. Resuscitation of premature infants with $100 \% \mathrm{O}_{2}$ resulted in $\mathrm{SpO}_{2}$ values above the upper limit of the $2010 \mathrm{NRP}$ guidelines (Figure 1 - red line; open diamonds); $40 \% \mathrm{O}_{2}$ resuscitated group had mean $\mathrm{SpO}_{2}$ values below the NRP lower limit in the first five minutes and within the NRP defined $\mathrm{SpO}_{2}$ target range from 6 to 10 minutes (Figure 1 - blue line; open circles); $21 \% \mathrm{O}_{2}$ resuscitated group had mean $\mathrm{SpO}_{2}$ values bordering the NRP lower limit in the first five minutes and within the NRP defined $\mathrm{SpO}_{2}$ target range from 6 to 10 minutes (Figure 1 - green line; closed squares). Similarly, there were no differences in $\mathrm{SpO}_{2}$ at 10 and 30 minutes after birth among the groups [20]. Infants in $21 \% \mathrm{O}_{2}, 40 \% \mathrm{O}_{2}$ and $100 \% \mathrm{O}_{2}$ groups were weaned to $24.8 \%( \pm 5), 27.9 \%( \pm 6)$ and $38 \%( \pm 20) \mathrm{O}_{2}$ respectively at 30 minutes of age (Figure 2) [20]. Despite aggressive weaning, $\mathrm{FiO}_{2}$ administered was significantly higher in the $100 \% \mathrm{O}_{2}$ group to maintain the target $\mathrm{SpO}_{2}$ until 30 minutes of age; however, there was no significant difference in $\mathrm{FiO}_{2}$ between $40 \% \mathrm{O}_{2}$ and $21 \% \mathrm{O}_{2}$ groups during the weaning process (Figure 2). The novelty of this study was in administering a fixed concentration of oxygen and blinding the study gas for the first 10 minutes irrespective of the $\mathrm{SpO}_{2}$. This pilot study demonstrate that resuscitation with $21 \% \mathrm{O}_{2}$ is feasible and the evolution of $\mathrm{SpO}_{2}$ in the first 10 minutes following $21 \% \mathrm{O}_{2}$ resuscitation are fairly close to NRP 


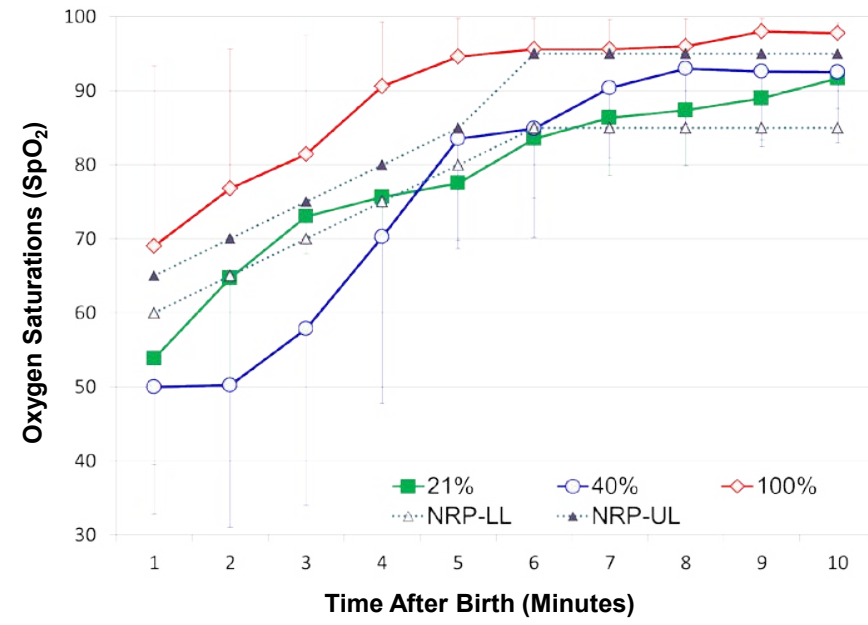

Figure 1. Oxygen saturations $\left(\mathrm{SpO}_{2}\right)$ in premature infants $<32$ weeks $\mathrm{GA}$ during the first 10 minutes after birth in the three resuscitated groups. The concentration of oxygen was constant for the first 10 minutes at $21 \% \mathrm{O}_{2}$ [--; green]; $40 \% \mathrm{O}_{2}$ [-०-; blue] and $100 \% \mathrm{O}_{2}$ $[-\diamond-;$ red $]$ in the three groups. Each time point represents mean $\pm \mathrm{SD} . \mathrm{SpO}_{2}$ significantly increased over time in the first 10 minutes after birth in all infants $(\mathrm{P}<0.0001$ mixed model ANOVA). Upper ( $\cdots \mathbf{\Lambda} \cdots)$ and lower $\left(\cdots \Delta^{\cdots}\right) \mathrm{SpO}_{2}$ limits (NRP 2010 guidelines) are superimposed on the $\mathrm{SpO}_{2}$ curves of the three $\mathrm{O}_{2}$ resuscitated groups. $\mathrm{SpO}_{2}$ in the $100 \%$ $\mathrm{O}_{2}$ group was above NRP-upper limit; resuscitation with $21 \%$ or $40 \% \mathrm{O}_{2}$ maintained $\mathrm{SpO}_{2}$ within the NRP range from 5 to 10 minutes of life. (with permission of the authors)

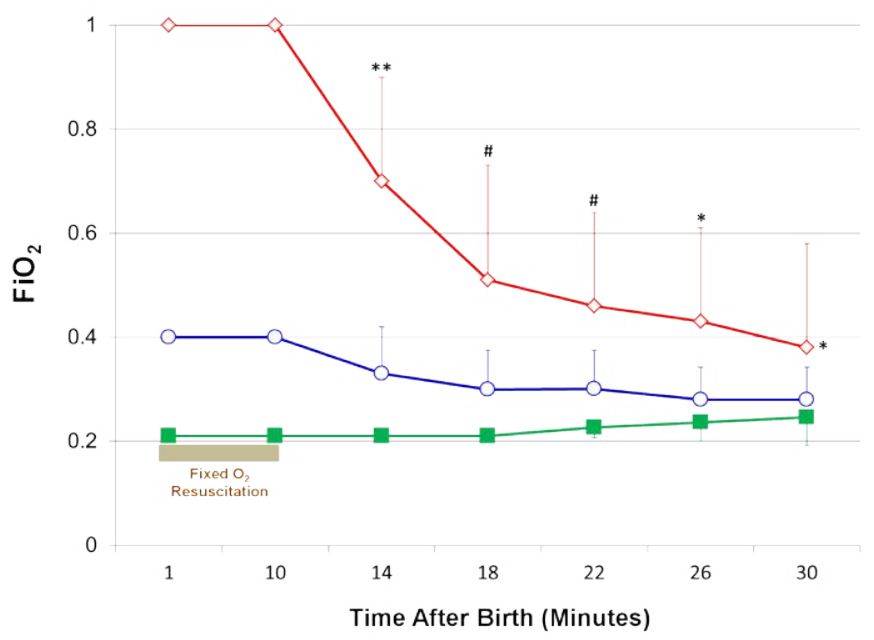

Figure 2. $\mathrm{FiO}_{2}$ in the first 30 minutes after birth in the three oxygen resuscitated groups. Oxygen concentration was constant during resuscitation for the first 10 minutes after birth at $21 \% \mathrm{O}_{2}$ [---; green]; $40 \% \mathrm{O}_{2}\left[-\mathrm{-}_{-}\right.$; blue $]$and $100 \% \mathrm{O}_{2}\left[-\diamond_{-} ;\right.$red $]$in the three groups. $\mathrm{FiO}_{2}$ was adjusted from 10 to 30 minutes of age for a target $\mathrm{SpO}_{2}$ of $85-95$. $\mathrm{FiO}_{2}$ was significantly higher in the $100 \% \mathrm{O}_{2}$ group to maintain the target $\mathrm{SpO}_{2}$ from 10 to 30 minutes of age $\left({ }^{*} \mathrm{p}<0.02\right.$ versus $40 \% \mathrm{O}_{2} \& 21 \% \mathrm{O}_{2}$ groups; Mixed model repeated measure); ${ }^{*} \mathrm{p}<$ $0.0001 ; \# \mathrm{p}<0.002 ; * \mathrm{p}<0.02$ versus $40 \% \mathrm{O}_{2} \& 21 \% \mathrm{O}_{2}$ groups; ANOVA. (with permission of the authors)

saturation limits. However, low enrollment is a major limitation of the study, leading to lack of clinical significance to study results.

Despite the lack of evidence regarding the appropriate $\mathrm{SpO}_{2}$ ranges at resuscitation in premature infants, particularly in extremely low birth weight infants, studies suggest that using high oxygen concentration at resuscitation is not beneficial [21]. Resuscitation guidelines released last year recommend against using high oxygen concentrations $\left(65 \% \mathrm{O}_{2}\right.$ - $100 \% \mathrm{O}_{2}$ ) and to administer $21 \% \mathrm{O}_{2}-30 \% \mathrm{O}_{2}$ to initiate resuscitation. Administering low oxygen concentrations has not been conclusively proven to improve outcomes. Nonetheless, it decreases the oxygen load exposed in the first 30 minutes after birth contributing to improvement in oxidative stress markers in these infants $[10,20]$.

In a non-asphyxiated premature or term infant administering low concentration of oxygen and titrating it based on saturation limits is prudent at the present time. However, in an asphyxiated infant, whether term or preterm, the oxygen resuscitation guidelines are not clear-cut. It is recommended that oxygen concentration be increased to $100 \% \mathrm{O}$ in a bradycardic / asystolic infant, until heart rate recovers to normal [7]. The key determinant of neonatal resuscitation is more likely to be the heart rate rather than oxygenation. Reperfusion-reoxygenation may lead to additional injury beyond that generated by hypoxia-ischemia alone. Free radicals are produced when myocardium is perfused following ischemia, injuring myocytes \& endothelial cells. The release of free radicals, in combination with ischemia deplete intracellular antioxidant activity, rendering myocardium extremely vulnerable to further insult. Weaning and titrating the oxygen concentration to defined saturation targets with pulse oximetry in place is probably the best course at this time. Research into the critical role of heart rate and the myocardial oxygen dynamics at resuscitation, its responses to oxygenation and ultimately on long-term neurodevelopmental outcomes will determine the oxygen concentration after birth.

\section{References}

1. Saugstad OD (1990) Oxygen toxicity in the neonatal period. Acta Paediatr Scand 79 881-892. [Crossref]

2. Jobe AH, Ikegami M (1998) Mechanisms initiating lung injury in the preterm. Early Hum Dev 53: 81-94. [Crossref]

3. Ashton N, Ward B, Serpell G (1954) Effect of oxygen on developing retinal vessels with particular reference to the problem of retrolental fibroplasia. Br J Ophthalmol 38: 397-432. [Crossref]

4. Mickel HS, Vaishnav YN, Kempski O, von Lubitz D, Weiss JF, et al. (1987) Breathing $100 \%$ oxygen after global brain ischemia in Mongolian Gerbils results in increased lipid peroxidation and increased mortality. Stroke 18: 426-30. [Crossref]

5. Dawson JA, Kamlin CO, Vento M, Wong C, Cole TJ, et al. (2010) Defining the reference range for oxygen saturation for infants after birth. Pediatrics 125: e1340-7. [Crossref]

6. Kamlin CO, O'Donnell CP, Davis PG, Morley CJ (2006) Oxygen saturation in healthy infants immediately after birth. J Pediatr148: 585-589. [Crossref]

7. Kattwinkel J, Perlman JM, Aziz K, Colby C, Fairchild K, et al. (2010) Neonatal resuscitation: 2010 American Heart Association Guidelines for Cardiopulmonary Resuscitation and Emergency Cardiovascular Care. Pediatrics 126: e1400-1413. [Crossref]

8. Perlman JM, Wyllie J, Kattwinkel J, Wyckoff MH, Aziz K, et al. (2015) Part 7: Neonatal Resuscitation: 2015 International Consensus on Cardiopulmonary Resuscitation and Emergency Cardiovascular Care Science With Treatment Recommendations. Circulation 132: S204-241.

9. Escrig R, Arruza L, Izquierdo I, Villar G, Saenz P, et al. (2008) Achievement of targeted saturation values in extremely low gestational age neonates resuscitated with low or high oxygen concentrations: a prospective, randomized trial. Pediatrics 121: 875-881. [Crossref]

10. Vento M, Moro M, Escrig R, Arruza L, Villar G, et al. (2009) Preterm resuscitation with low oxygen causes less oxidative stress, inflammation, and chronic lung disease. Pediatrics 124: e439-449. [Crossref]

11. Rook D, Schierbeek H, Vento M, Vlaardingerbroek H, van der Eijk AC, et al. (2014) Resuscitation of preterm infants with different inspired oxygen fractions. J Pediatr 164: 1322-1326. [Crossref]

12. Dawson JA, Kamlin CO, Wong C, te Pas AB, O'Donnell CP, et al. (2009) Oxygen saturation and heart rate during delivery room resuscitation of infants $<30$ weeks gestation with air or $100 \%$ oxygen. Arch Dis Child Fetal Neonatal Ed 94: F87-91. [Crossref]

13. Rabi Y, Singhal N, Nettel-Aguirre A (2011) Room-air versus oxygen administration for 
resuscitation of preterm infants: the ROAR study. Pediatrics 128: e374-381. [Crossref]

14. Wang CL, Anderson C, Leone TA, Rich W, Govindaswami B, et al. (2008) Resuscitation of preterm neonates by using room air or 100\% oxygen. Pediatrics 121: 1083-1089. [Crossref]

15. Frank L, Sosenko IR (1987) Development of lung antioxidant enzyme system in late gestation: possible implications for the prematurely born infant. J Pediatr 110: 9-14. [Crossref]

16. Finne PH, Halvorsen S (1972) Regulation of erythropoiesis in the fetus and newborn. Arch Dis Child 47: 683-687. [Crossref]

17. Von Kohorn I, Ehrenkranz RA (2009) Anemia in the preterm infant: erythropoietin versus erythrocyte transfusion--it's not that simple. Clin Perinatol 36: 111-123. [Crossref]
18. Dudell G, Cornish JD, Bartlett RH (1990) What constitutes adequate oxygenation? Pediatrics 85: 39-41. [Crossref]

19. Yu AY, Frid MG, Shimoda LA, Wiener CM, Stenmark K, et al. (1998) Temporal, spatial, and oxygen-regulated expression of hypoxia-inducible factor-1 in the lung. $\mathrm{Am}$ J Physiol 275: L818-826. [Crossref]

20. Kumar HSV, Carrion V, Wynn KA, Nielsen L, Reynolds AM, et al. (2014) Oxygen resuscitation and oxidative stress biomarkers in premature infants. Research and Reports in Neonatology 4: 91-99.

21. Davis PG, Tan A, O’Donnell CP, Schulze A (2004) Resuscitation of newborn infants with $100 \%$ oxygen or air: a systematic review and meta-analysis. Lancet 364: 13291333. [Crossref]

Copyright: (C2016 Kumar VHS. This is an open-access article distributed under the terms of the Creative Commons Attribution License, which permits unrestricted use, distribution, and reproduction in any medium, provided the original author and source are credited. 